\title{
大学生の援助要請行動と 自己愛の関連についての探索的検討
}

\author{
齋藤由布 \\ (横浜国立大学大学院教育学研究科) \\ キーワード : 援助要請行動, 自己愛, 大学生
}

\begin{abstract}
Exploratory examination of relation between help-seeking behavior and narcissism
Yu Saito
\end{abstract}

(Graduate School of Education, Yokohama National University)

Key words: help-seeking behavior, narcissism, university student

\section{I . 問題と目的}

我々は生活する中で，困った状況や苦しい状況を経験する ことがある。そうした状況を解決するために他者からの援助 が建設的に働く場合, 適切な援助要請をすることは問題の悪 化を防ぎ適応を促進するために重要であるといえよう。しか し, 何らかの要因によって援助要請が容易には起こらない場 合があることが先行研究で指摘されている(たとえば Kushner \& Sher, 1989)。

援助要請について DePaulo(1983)は「もし他者が時間, 労 力，あるいはある種の資源を費やしてくれるのなら解決，軽 減するような問題を抱えている個人が，その他者に対して直 接的に援助を要請する行動である」と説明している。本研究 ではこの定義に基づき, 援助要請の特に行動的側面に焦点を あて, 援助要請行動 (help-seeking behavior, 以下 HS) に ついて検討する。HS は, 解決すべき問題の内容や状況によ つて関連する要因や付随する行動が異なると考えられる。し たがって HS を検討する際には, 問題の内容や状況に基づい て適切に分類することが必要であるといえる。しかしながら， HS を分類した上で検討寸る試みは未だ少なく不十分である と考えられる。また，個人の自らに対する「援助を求めても よい人間である」という思いや，他人に助けを求めることに 対する「プライドにかかわる」あるいは「相手の迷惑になる」 などの考えの有無や強さは, HS の生起に関連していると考 えられる。これらには自己愛の強さや高さが関連していると 考えられるが，これまでの研究ではHS と自己愛との関連は 検討されていない。

そこで本研究では，HS を類型化し(目的 1)，自己愛との関 連について探索的な検討を試みる(目的 2)。なお，その際には 自己愛を誇大性と過敏性の 2 種類に大別して捉える考え方 (Gabbard, 1994)に基づき検討する。

\section{II. 方法}

調査対象: 大学生 - 大学院生 301 名 $(\mathrm{M}=131, \mathrm{~F}=170$, $20.21 \pm 1.83$ 歳)

調查時期 : 2007 年 9 10 月

調查方法 : 個別記入式の質問紙調查を行った。本研究では次 の 48 項目について検討する。(1)援助要請行動尺度 : 野崎 石井(2004)を元に作成した 30 項目の状況について,HS を「絶 対に行わない」「おそらく行わない」「どちらともいえない」 「おそらく行う」「必ず行う」の 5 件法で問うもの。(2)評価 過敏性一誇大性自己愛尺度（中山・中谷, 2006）計 18 項目 5 件法。

\section{III. 結果と考察}

目的 1 の検討: 援助要請行動尺度について因子分析 (主因子法, プロマックス回転)を行った結果, 緊急事態における緊急的 HS, ものや道具的な知識の提供を求める道具的 HS, 相手の
労力の提供を求める労力的 HS，心理的なサポートを求める 心理的 HS, 金銭の提供あるいは金銭を介した労力の提供を 求める経済的 HS の 5 因子が得られた。因子ごとに負荷量の 高い項目の平均得点を算出し, 各因子に対応する下位尺度得 点とした。

目的 2 の検討 : 誇大性と過敏性の高低を極とする 2 軸を想定 し, 誇大性, 過敏性のどちらか一方の性質を強く持つ人（「誇 大群」「過敏群」), 両性質を共に強く持つ人 (「混合群」), 共 に弱く持つ人（「低自己愛群」）の 4 群に対象者の類型化を行 ったところ, 群間に偏りなく形成できた $(x=4.16, d f=3, n . s$.$) 。$

そこで，この自己愛の 4 類型と目的 1 で得られた HS の 5 種類を用いて $4 \times 5$ の 2 要因分散分析を行った。その結果, 交互作用は有意ではなかったため $(F(10.77,1040.68)=1.608$, $p>.05)$, 主効果の検討を行った。まず，自己愛の類型による 主効果が有意であったため $(F(3,163)=4.32, p<.01)$, 多重比 較（Bonferroni の方法）を行ったところ, 誇大群と過敏群, 誇大群と低自己愛群の間に有意傾向のある差がみられた。具 体的には, 誇大群>過敏群＝低自己愛群という差がみられた。 このことから, 自己愛の類型が HS に影響を与えること, 特 に自己愛の誇大性の低さが HS の起きにくさに関連している 可能性が示された。次に, HS の種類による主効果も有意で あったため $(F(4,652)=167.51, p<.01)$, 同様に多重比較を行 ったところ，緊急的 HS および道具的 HS と心理的 HS との 間, さらに心理的 HS と労力的 HS および経済的 HS との間 にいずれも $1 \%$ 水準で有意な差がみられた。具体的には，緊 急的 $\mathrm{HS}=$ 道具的 $\mathrm{HS}>$ 心理的 $\mathrm{HS}>$ 労力的 $\mathrm{HS}=$ 経済的 $\mathrm{HS}$ という差がみられた。

本研究は, HS を問題の内容や状況に基づき類型化した上 で, 自己愛という新たな視点を加えて検討した点で有意義で あったといえる。今後は, 援助を求める対象や HS にかかわ る認知的要因など, 今回検討しなかった要因についても検討 を重ねていくこと，HS が精神的健康にどう関連しているの かについても検討することなどが必要とされる。

\section{【引用文献】}

DePaulo, B.M. 1983 Perspectives on help-seeking. In DePaulo, B.M., Nedler, A., \& Fisher, J.D.(Eds.), New Directions in Helping. Volume 2 Help-seeking. New York : Academic Press. Pp.3-12.

Kushner, M.G. \& Sher, K.J. 1989 Fear of psychological treatment and its relation to mental health service avoidance. Professional Psychology:Research and Practice, 20(4), 251-257.

中山留美子 - 中谷素之 2006 青年期における自己愛の構造と発達 的変化の検討 教育心理学研究，54，188-198.

野崎秀正 - 石井眞治 2004 抑制要因に基づく大学生の援助要請 行動の分類 広島大学大学院教育学研究科紀要第一部, 53, 49-54. 